\title{
Telmisartan w leczeniu nadciśnienia tętniczego — optymalny wybór zgodny z wytycznymi Polskiego Towarzystwa Nadciśnienia Tętniczego 22015 roku
}

\section{Telmisartan in the treatment of hypertension — optimal choice according to guidelines PTNT 2015}

\author{
Krystyna Widecka \\ Klinika Hipertensjologii i Chorób Wewnętrznych Pomorskiego Uniwersytetu Medycznego w Szczecinie
}

\section{Summary}

In recent years emphasis in the treatment of hypertension has been put on the individualization of treatment. The recently published guidelines of the Polish Society of Hypertension list several clinical situations in which use of angiotensin II receptor blockers (ARBs) is indicated.

Blockade of the renin-angiotensin- aldosterone system plays a pivotal role in the treatment of high blood pressure and prevention of target organ damage. Telmisartan is an angiotensin II receptor blocker displaying beneficial unique pharmacologic properties, metabolic effects, antihypertensive efficacy in monotherapy and combinations and good tolerance. Clinical studies confirm that telmisartan improves endothelial function, insulin sensitivity and lipid profiles, reduces arterial stiffness. In addition, telmisartan improves renal function and has potential beneficial effects on prevention of cerebrovascular disease. The Ongoing Telmisartan Alone and in Combination with Ramipril Global Endpoint Trial (ONTARGET) study has shown that telmisartan provides similar cardiovascular protection to ramipril in high-risk patients, while being better tolerated.

key words: telmisartan, angiotensin II receptor blockers, hypertension, guidelines

Arterial Hypertens. 2015, vol. 19, no. 4, pages: 145-151

DOI: $10.5603 / A H .2015 .0019$

\section{Wprowadzenie}

Antagoniści receptora angiotensyny II (ARBs, angiotensin receptor blocker; sartany) to nowoczesna grupa leków hipotensyjnych o dużej skuteczności w prewencji sercowo-naczyniowej, potwierdzonej w dużych badaniach klinicznych. Sztandarowe badania medycyny opartej na faktach (EBM, Evidence Based Medicine) w prewencji chorób sercowo-naczyniowych dla tej grupy leków przedstawiono na rycinie 1 .

Sartany siłą efektu hipotensyjnego nie ustępują diuretykom, beta-adrenolitykom, inhibitorom kon-

Adres do korespondencji: prof. dr hab. n. med. Krystyna Widecka

Klinika Hipertensjologii i Chorób Wewnętrznych SPSK-1 PUM

ul. Unii Lubelskiej 1, 71-252 Szczecin

tel.: (91) 4253550, faks: (91) 4253552

e-mail: widecka@o2.pl

V M Copyright $@ 2015$ Via Medica, ISSN 2449-6170 


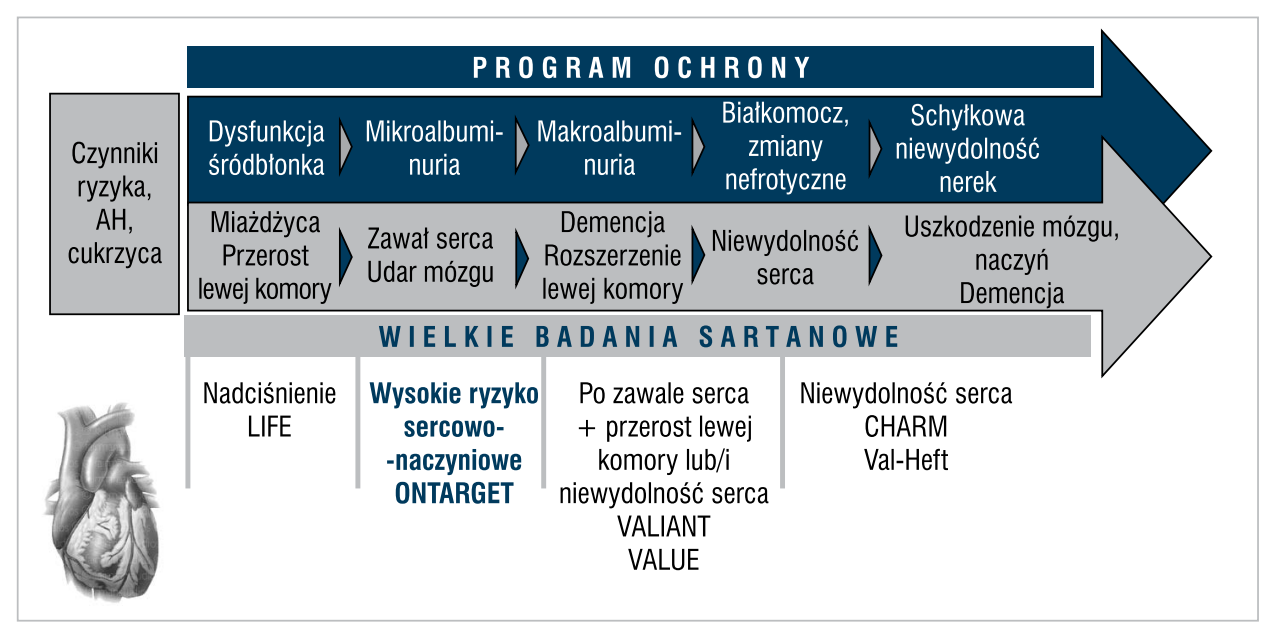

Rycina 1. Prewencja zdarzeń sercowo-naczyniowych w badaniach klinicznych; AH (arterial hypertension) — nadciśnienie tętnicze

wertazy angiotensyny (ACE-I, angiotensin converting enzyme inhibitors) i antagonistom wapnia, ponadto charakteryzują się dodatkowymi korzystnymi działaniami, niezależnymi od obniżania wartości ciśnienia tętniczego (BP, blood pressure) [1].

W najnowszych zaleceniach Polskiego Towarzystwa Nadciśnienia Tętniczego (PTNT) preparaty ARBs należą do pięciu gównych grup leków stosowanych w leczeniu hipotensyjnym, wykorzystywanych zarówno w monoterapii, jak i w leczeniu skojarzonym [2].

Przyjęta w aktualnych i poprzednich wytycznych strategia leczenia farmakologicznego nadciśnienia tętniczego $(\mathrm{AH}$, arterial hypertension) kładzie nacisk na jego indywidualizację. Ze względu na potencjalne korzyści pozahipotensyjne udokumentowane w dużych badaniach klinicznych ważne znaczenie ma wybór terapii pierwszego rzutu $[2,3]$. Biorąc pod uwagę indywidualne wskazania, sartany należą do leków pierwszego wyboru w następujących sytuacjach klinicznych:

- przerost lewej komory serca;

- przebyty udar mózgu;

- zespół metaboliczny;

- cukrzyca;

- pacjent wysokiego ryzyka (mnogie powikłania sercowo-naczyniowe i metaboliczne) - w tym wskazaniu tylko telmisartan;

- dna moczanowa (preferowany losartan);

- albuminuria/białkomocz;

- przewlekła choroba nerek cukrzycowa/niecukrzycowa;

- niewydolność nerek;

- zaburzenia potencji;

- astma oskrzelowa/przewlekła obturacyjna choroba płuc.
Zgodnie z wytycznymi preparaty ARBs należą do leków drugiego wyboru w następujących sytuacjach klinicznych:

- choroba niedokrwienna serca (przy nietolerancji ACE-I) - preferowane telmisartan i walsartan;

- niewydolność serca (przy nietolerancji ACE-I) preferowane kandesartan i walsartan;

- nadciśnienie tętnicze u osób w podeszłym wieku;

- izolowane nadciśnienie skurczowe;

- pacjent wysokiego ryzyka (mnogie powikłania sercowo-naczyniowe i metaboliczne) przy nietolerancji ACE-I, poza telmisartanem, który ma status leku I wyboru na równi z ACE-I. [2]

Mimo że sartany to najbardziej homogenna grupa leków hipotensyjnych i można by się pokusić o obronę zasady „efektu klasy”, to jednak status poszczególnych preparatów różni się chociażby badaniami klinicznymi. Przy wyborze konkretnego leku należy wziąć pod uwagę stopień $\mathrm{AH}$, globalne ryzyko sercowo-naczyniowe pacjenta, choroby współistniejące, dowody na uzyskane korzyści w określonym rozpoznaniu powikłań sercowo-naczyniowych, a także dowody na działanie w skojarzeniu z innymi lekami hipotensyjnymi [1-3].

W wytycznych PTNT z 2015 roku w przypadku powikłań sercowych zdecydowano się, preferując leki ze względu na wskazania dodatkowe, na rekomendowanie nowszych preparatów ARBs, przyznając telmisartanowi pozycję zdecydowanego lidera. W swojej grupie telmisartan jest lekiem o potwierdzonej klinicznie skuteczności hipotensyjnej i charakteryzuje się szczególnie korzystnymi cechami w zakresie profilu farmakokinetycznego, wpływem na zaburzenia metaboliczne oraz dobrą tolerancją przez pacjentów. W świetle opublikowanych w 2008 roku wyników szeroko zakrojonych badań ONgoing Telmisartan Alone 
and in Combination with Ramipril Global Endpoint Trial (ONTARGET) i Telmisartan Randomized Assesment Study in ACEI Intolerant Subjects with Cardiovascular Disease (TRANSCEND) lek ten można uznać za skuteczny w zapobieganiu incydentom związanym z miażdżycą u chorych z AH, obciążonych dużym ryzykiem sercowo-naczyniowym $[4,5]$.

\section{Unikatowe właściwości farmakologiczne telmisartanu}

Telmisartan wyróżnia się szczególnie korzystnym profilem farmakokinetycznym. Jego hipotensyjny efekt jest wynikiem długotrwałej i selektywnej blokady receptorów AT1 dla angiotensyny II. Na podstawie badań in vitro ustalono, że ma on największe powinowactwo do wiązania z ludzkim receptorem angiotensyny II typu 1 spośród wszystkich znanych sartanów. Należy również podkreślić, że telmisartan jest najbardziej lipofilnym ARB, co ułatwia mu dyfuzję przez błony komórkowe i dotarcie do trudno dostępnych kompartmentów tkankowych $[6,7]$.

Po podaniu doustnym telmisartan szybko wchłania się z przewodu pokarmowego, osiągając maksymalne stężenie we krwi $\mathrm{w}$ czasie od 0,5 do 1,5 godziny. Jego całkowita biodostępność wynosi około $50 \%$ i tylko w niewielkim stopniu zmniejsza ją przyjmowanie leku łącznie z pokarmem. Zatem niezależnie od tego, czy telmisartan jest przyjmowany na czczo, czy po posiłku, jego stężenie w osoczu po 3 godzinach od podania osiaga podobny poziom. Telmisartan odznacza się największą objętością dystrybucji spośród wszystkich ARA, wynoszącą około 500 l. Dzięki temu może w większym stopniu od innych sartanów penetrować do tkanek obwodowych, gwarantując blokadę układu renina-angiotensyna-aldosteron (RAA, renin-angiotensin-aldosterone) zarówno miejscową, jak i ogólnoustrojową [7]. Preparat ten jest metabolizowany w wątrobie i podlega powolnej eliminacji. Większa część podanej dawki (> 97\%) zostaje usunięta drogą wydalania żółciowego z kałem. Z moczem są wydalane jedynie niewielkie ilości $(<1 \%)$ leku. Wyróżnia to telmisartan spośród innych antagonistów angiotensyny i w dużym stopniu uniezależnia jego farmakokinetykę od zaburzeń czynności nerek [8].

Telmisartan charakteryzuje się korzystnym profilem działania hipotensyjnego, które utrzymuje się przez 24 godziny od przyjęcia leku i obejmuje okres ostatnich 4 godzin przed przyjęciem następnej dawki. $\mathrm{Na}$ podstawie badań klinicznych parametr through to peak ratio dla telmisartanu, określający maksymalne obniżenie BP i obniżenie ciśnienia bezpośrednio przed przyjęciem kolejnej dawki leku, oszacowano na powyżej $80 \%$ zarówno po podaniu dawki $40 \mathrm{mg}$, jak i $80 \mathrm{mg}$. Ten długotrwały efekt hipotensyjny telmisartanu ma istotne znaczenie kliniczne $\mathrm{w}$ aspekcie zapobiegania porannemu wzrostowi BP [9], co jest o tyle ważne, że we wczesnych godzinach porannych odnotowuje się zwiększoną zapadalność na powikłania $\mathrm{AH}$, takie jak ostry zespół wieńcowy i udar mózgu [10]. Ponadto, całodobowe działanie telmisartanu przy dawkowaniu raz na dobę pozwala na prosty schemat leczenia i sprzyja przestrzeganiu zaleceń przez pacjentów [9].

\section{Zastosowanie kliniczne telmisartanu}

Pacjent wysokiego ryzyka sercowo-naczyniowego W wytycznych PTNT z 2015 roku u pacjenta wysokiego ryzyka sercowo-naczyniowego (mnogie powikłania sercowo-naczyniowe i metaboliczne) pozycję leku pierwszego wyboru na równi z ACE-I (perindoprilem i ramiprilem) przyznano telmisartanowi [2]. Należy podkreślić, że pozostałe sartany w tym wskazaniu są lekami drugiego wyboru przy nietolerancji ACE-I.

Argumentem uzasadniającym powyższą decyzję były wyniki badania ONTARGET [4], którego celem była odpowiedź na pytanie, czy u chorych obciążonych dużym ryzykiem sercowo-naczyniowym, bez niewydolności serca, stosowanie telmisartanu jest nie mniej skuteczne w zapobieganiu incydentom naczyniowym oraz czy terapia skojarzona dwoma lekami jest korzystniejsza od leczenia samym ramiprylem. Wykazano, że telmisartan nie ustępuje ramiprylowi pod względem redukcji częstości występowania pierwszorzędowego punktu końcowego, jak również drugorzędowego punktu końcowego złożonego $\mathrm{z}$ incydentów zawału serca, udaru mózgu lub zgonu z przyczyn sercowo-naczyniowych.

Dodatkowo w grupie telmisartanu liczba pacjentów przerywających leczenie była istotnie mniejsza niż w przypadku osób stosujących ramipryl, nawet mimo fazy wstępnej badania, w której celem było dopuszczenie do randomizacji tylko tych osób, które dobrze tolerowały oba proponowane leki.

W podsumowaniu badania ONTARGET jego autorzy stwierdzają, że u chorych obciążonych dużym ryzykiem sercowo-naczyniowym, bez objawowej niewydolności serca, stosowanie telmisartanu było równie skuteczne pod względem zapobiegania incydentom sercowo-naczyniowym, a dodatkowo lepiej tolerowane niż leczenie ramiprylem. $\mathrm{Na}$ podstawie tego badania Europejska Agencja Leków (EMA, European Medicines Agency) zatwierdziła nowe wskazanie dla telmisartanu $\mathrm{w}$ dawce $80 \mathrm{mg}$, to jest 
możliwość stosowania w prewencji incydentów sercowo-naczyniowych w celu zmniejszenia częstości zachorowań z przyczyn sercowo-naczyniowych u pacjentów wysokiego ryzyka, to znaczy z jawnymi powikłaniami choroby zakrzepowo-zatorowej (choroba wieńcowa, udar, miażdżyca zarostowa tętnic kończyn dolnych), a także z cukrzycą typu 2 z udokumentowanymi uszkodzeniami narządów docelowych. Należy zwrócić uwagę na trzy bardzo istotne elementy:

- jest to niezależne wskazanie obok wcześniejszego zalecenia do leczenia samoistnego AH u dorosłych;

- oba wskazania różnią się zalecaną dawką. W przypadku leczenia hipotensyjnego zazwyczaj stosuje się $40 \mathrm{mg}$ raz na dobę, w razie potrzeby dawkę można zmniejszyć do $20 \mathrm{mg}$ lub zwiększyć do $80 \mathrm{mg}$. W prewencji incydentów sercowo-naczyniowych zalecana dawka to $80 \mathrm{mg}$ raz na dobę. Brak jest dowodów klinicznych na to, czy mniejsza dawka będzie równie skuteczna. Obawy o nadmierny efekt hipotensyjny w grupie chorych z dobrze kontrolowanym BP rozwiały wyniki badania ONTARGET, w którym chorzy wysokiego ryzyka z prawidłowym BP otrzymujący telmisartan w dawce $80 \mathrm{mg}$ odnosili duże korzyści kliniczne i nie obserwowano u nich nadmiernego spadku ciśnienia tętniczego;

- jest to aktualnie jedyny sartan mający rejestrację dla profilaktyki incydentów sercowo-naczyniowych.

\section{Pacjent z nadciśnieniem tętniczym niepowikłanym}

Dotychczasowe badania kliniczne: EValuation de l'Efficacité RESiduelle du TElmisartan (EVERESTE), The Angiotensin II Receptor Antagonist Micardis in Isolated Systolic hypertension (ARAMIS), Prospective, Randomized Investigation of the Safety and efficacy of Micardis versus ramipril using ABPM (PRISMA), MICArdis Missed DOse Study (MICADO II) wykazały dużą skuteczność telmisartanu w monoterapii łagodnego lub umiarkowanego $\mathrm{AH}$, porównywalną z pozostałymi preparatami ARBs, jak również z lekami hipotensyjnymi z innych grup [11-14].

W leczeniu skojarzonym korzystne pod względem skuteczności hipotensyjnej okazało się połączenie telmisartanu z hydrochlorotiazydem, co ma sumujące się działanie przeciwnadciśnieniowe powodujące zmniejszenie BP w większym stopniu niż w wypadku każdego składnika osobno. Preparat ten podany raz na dobę wywołuje efektywne i regularne zmniejszenie ciśnienia krwi we wszystkich dawkach terapeutycznych.

Badania kliniczne zgodnie wykazały, że dołączenie hydrochlorotiazydu, nawet w małej dawce, zwiększa efekt hipotensyjny leczenia, bez niekorzystnego wpływu na bezpieczeństwo terapii i prowadzi do zależnego od dawki obniżenia BP [15]. Połączenie telmisartanu $\mathrm{z}$ hydrochlorotiazydem było porównywane głównie z preparatami złożonymi, w skład których wchodził inny ARB i hydrochlorotiazyd. Godne uwagi jest to, że w ramach przeprowadzonych badań oprócz klinicznych pomiarów BP wykonanych w czasie, gdy lek wykazywał najsłabsze działanie, wykonano ambulatoryjne pomiary ciśnienia tętniczego (ABPM, ambulatory blood pressure monitoring) w celu oceny tego, w jakim stopniu kontrolowane jest średnie BP w okresie pomiędzy kolejnymi dawkami leku. Wyniki badań wskazują, że preparat złożony telmisartan/hydrochlorotiazyd wykazuje większą skuteczność w obniżaniu BP w okresie poprzedzającym przyjęcie kolejnej dawki (okres zwiększonego ryzyka sercowo-naczyniowego) w porównaniu z preparatem złożonym losartan/ /hydrochlorotiazyd [16].

\section{Pacjent $\mathrm{z}$ nadciśnieniem i zespołem metabolicznym}

Nadciśnienie tętnicze często wchodzi w skład zespołu metabolicznego, współistniejąc z zaburzeniami gospodarki węglowodanowej i lipidowej. Stąd ważne jest, by terapia hipotensyjna u pacjentów z zespołem metabolicznym była prowadzona lekami, które nie przyspieszają występowania cukrzycy [17]. Zastosowanie znalazły tu przede wszystkim leki blokujące układ RAA. Potencjalnie korzystne działanie ARBs w prewencji cukrzycy wynika z ochronnego wpływu na komórki beta wysp Langerhansa oraz zwiększenia wrażliwości tkanek na insulinę. Zmniejszają one włóknienie wysp Langerhansa, a dodatkowo redukują stres oksydacyjny, co w efekcie powoduje zwiększenie wydzielania insuliny przez komórki beta [18]. Dzięki zwiększeniu wrażliwości tkanek na insulinę leki te prowadzą do obniżenia stężenia triglicerydów, cholesterolu frakcji LDL (low density lipoprotein lipoproteiny o niskiej gęstości), zwiększenia cholesterolu frakcji HDL (high density lipoprotein - lipoproteiny o dużej gęstości) oraz mogą hamować uwalnianie niektórych mediatorów i cytokin zapalnych, a w konsekwencji przyczyniać się do redukcji ryzyka miażdżycy tętnic [19].

Interesujące jest badanie, w którym oceniano zdolność różnych ARBs do aktywacji PPAR- $\gamma$. Przy wysokim stężeniu tych leków telmisartan jako jedyny powodował aktywację receptorów jądrowych. Należy jednak podkreślić, że działał on jako częściowy agonista PPAR- $\gamma$ także w niższych stężeniach, uzyskiwanych w warunkach fizjologicznych [20].

Badania kliniczne pacjentów z zespołem metabolicznym wykazały, że pod wpływem leczenia telmisartanem doszło u nich do znamiennego zmniejszenia 
stężenia glukozy we krwi oraz zwiększenia wrażliwości tkanek na insulinę, a co za tym idzie — obniżenia stężenia triglicerydów i zmniejszenia ryzyka miażdżycy tętnic [18]. Badania porównujące telmisartan i inne preparaty ARBs wskazują na istotne różnice na korzyść telmisartanu w zakresie wpływu na osoczowe stężenie insuliny, glukozy, triglicerydów, cholesterolu całkowitego i frakcji LDL, a także adiponektyny i mediatorów zapalnych [18].

\section{Pacjent z cukrzycą i nefropatią}

Częstość chorób nerek wzrasta wraz ze zwiększaniem się liczby pacjentów z AH oraz cukrzycą typu 2. Udowodniono, że skuteczna nefroprotekcja poprzez blokadę układu RAA zmniejsza ryzyko wystąpienia nefropatii i hamuje progresję chorób nerek [1-3].

W ostatnich latach dostarczono wiele dowodów na dużą skuteczność i dobrą tolerancję telmisartanu w leczeniu pacjentów z przewlekłą chorobą nerek (CKD, chronic kidney disease). Duże badania kliniczne porównały ten lek do „złotego standardu” w leczeniu CKD, jakim są preparaty ACE-I. W 2004 roku opublikowano wyniki wieloośrodkowego badania Diabetics Exposed to Telmisartan and Enalapril (DETAIL), w którym po raz pierwszy porównano wpływ $A R B$ reprezentowanego przez telmisar$\tan z$ przedstawicielem ACE-I - enalaprylem na hamowanie progresji niewydolności nerek u chorych na cukrzycę typu 2 współistniejącą z AH. Wykazano, że telmisartan jest tak samo skuteczny jak enalapril u pacjentów z AH i cukrzycą we wczesnym stadium nefropatii w zakresie zmniejszania wskaźnika filtracji kłębkowej (GFR, glomerular filtration rate) oraz dobrej kontroli parametrów nerkowych. Jest zatem jedynym z ARB, który można było porównać ze „złotym standardem" w tak długim okresie leczenia [21].

$\mathrm{Z}$ kolei celem badania Telmisartan versus Ramipril in renal Endothelial Dysfunkction (TRENDY) było wykazanie, że telmisartan poprawia funkcję śródbłonka naczyń nerkowych przynajmniej tak samo skutecznie jak ramipryl. U pacjentów uczestniczących w badaniu TRENDY wyjściowe stężenie albuminurii uległo istotnemu zmniejszeniu. Wpływ obu leków na wtórne punkty końcowe był porównywalny [22].

Nefroprotekcyjne działanie telmisartanu u pacjentów z cukrzycą i AH potwierdzono także w kolejnych trzech dużych badaniach: $A$ trial to inVestigate the efficacy of telmIsartan versus VALsartan in hypertensive type 2 DIabetic patientswith overt nephropathy (VIVALDI), A comparison of telMisartan versus losArtan in hypertensive type 2 DiabEtic patients with Overt nephropathy (AMADEO) i The Incipient to Overt: Angiotensin II Blocker, Telmisartan, Investigation on Type 2 Diabetic Nephropathy (INNOVATION) [23-25].
Celem badania VIVALDI z udziałem chorych na AH i cukrzycę typu 2 ze wspótistniejącą nefropatią cukrzycową była ocena skuteczności telmisartanu w hamowaniu regresji chorób nerek poprzez redukcję proteinurii u chorych na $\mathrm{AH}$ i cukrzycą typu 2 w porównaniu z walsartanem. $\mathrm{Na}$ podstawie wyników stwierdzono porównywalny wpływ telmisartanu w dawce $80 \mathrm{mg}$ i walsartanu w dawce $160 \mathrm{mg}$ na wydalanie białka z moczem i GFR w trakcie rocznej obserwacji [23].

W badaniu AMADEO porównywano skuteczność telmisartanu i losartanu w regresji chorób nerek poprzez redukcję proteinurii u chorych z AH i cukrzycą. Chorzy byli randomizowani do dwóch grup: $\mathrm{z}$ telmisartanem $\mathrm{w}$ dawce $80 \mathrm{mg}$ oraz losartanem w dawce $100 \mathrm{mg}$. Po 52 tygodniach obserwacji wykazano, że leczenie telmisartanem $\mathrm{w}$ porównaniu ze stosowaniem losartanu charakteryzuje się bardziej wyrażonym wpływem na zmniejszenie wydalania białka z moczem, przy porównywalnej skuteczność hipotensyjnej obu leków [24].

Warto także przytoczyć wyniki wieloośrodkowego, prospektywnego, randomizowanego, z podwójnie ślepą próbą badania INNOVATION, którego celem była ocena wpływu dużych i małych dawek telmisartanu na obniżenie mikroalbuminurii. W badaniu u pacjentów z cukrzycą typu 2, początkową nefropatią, z podwyższonym poziomem kreatyniny w surowicy, bez lub z AH. Punktami końcowymi było: przejście w stadium klinicznej nefropatii, podwojenie stężenia kreatyniny w surowicy, krańcowej niewydolności nerek (ESRD, end-stage renal disease) i zgon (zbiorowy punkt końcowy), zachorowalność i śmiertelność z przyczyn sercowo-naczyniowych (zbiorowy punkt końcowy).

Pacjenci otrzymywali telmisartan w rosnących dawkach: $20 \mathrm{mg}, 40 \mathrm{mg}, 80 \mathrm{mg}$ lub placebo. Po roku leczenia telmisartanem stwierdzono istotne zmniejszenie mikroalbuminurii [25].

Jak wynika z doświadczeń klinicznych, telmisartan zmniejsza mikroalbuminurię u pacjentów z $\mathrm{AH}$ oraz proteinurię w przebiegu nefropatii cukrzycowej i nefropatii bez podłoża cukrzycy, odznacza się większą skutecznością niż diuretyki u pacjentów z izolowanym skurczowym AH, jest bezpieczny u pacjentów z AH i różnymi stadiami niewydolności nerek oraz zwalnia postęp nefropatii cukrzycowej[26, 27].

\section{Pacjent z chorobą naczyniowo-mózgową}

Nadciśnienie tętnicze jest ważnym czynnikiem ryzyka udaru mózgu, a ciągła zależność między wysokością BP a częstością występowania udarów mózgu została jednoznacznie wykazana [28]. Dane z prób klinicznych dowodzą również, że stosunkowo 
nieznaczne obniżenie BP znacząco zmniejsza ryzyko udaru mózgu [29].

Ochronny wpływ ARBs na ośrodkowy układ nerwowy (OUN) nie ogranicza się jednak do działania hipotensyjnego, ale wynika również z selektywnej blokady receptorów AT1 z jednoczesnym pobudzeniem AT2 przez nagromadzoną wolną angiotensynę II. W badaniach na zwierzętach wykazano, że stymulacja receptorów AT2 przez angiotensynę zmniejsza obszar niedokrwienia mózgu. Ponadto sartany poprawiają krążenie mózgowe, zmniejszają napięcie ścian naczyń oraz wpływają na redukcję grubości intima-media w tętnicy środkowej mózgu [30].

Co prawda w badaniu Prevention Regimen for Effectively Avoiding Second Strokes (PROFESS) przeprowadzonym u pacjentów po przebytym udarze lub incydencie przemijającego niedokrwienia OUN obniżenie ciśnienia do $136 \mathrm{~mm} \mathrm{Hg}$ przez dołączenie do dotychczasowego leczenia telmisartanu nie wiązało się z istotnym zmniejszeniem częstości występowania ponownych udarów mózgu w porównaniu z grupą otrzymującą placebo [31]. W interpretacji badania należy jednak wziąć pod uwagę małą różnicę BP po leczeniu, krótki czas obserwacji (2,5 roku), a także częste stosowanie innego leczenia (wszyscy pacjenci otrzymywali leki przeciwpłytkowe, a połowa z nich leki hipolipemizujące), duży odsetek pacjentów, u których przerwano leczenie, czy też rozpoczynanie leczenia po upływie krótkiego czasu od wystąpienia incydentu naczyniowo-mózgowego, który kwalifikował chorych do udziału w tym badaniu.

Wpływ telmisartanu na funkcje poznawcze został zbadany wśród pacjentów z AH w podeszłym wieku [32]. W badaniu A Comparison of Telmisartan plus HCTZ with Amlodypine plus HCTZ in Older Patients with Predominantly Systolic Hypertension (ATHOS) telmisartan $80 \mathrm{mg}$ w połączeniu z hydrochlorotiazydem $12,5 \mathrm{mg}$ zapewniał nie tylko lepszą kontrolę BP, ale także miał lepsze wyniki w testach poznawczych w porównaniu z kombinacją lisinoprilu $20 \mathrm{mg}$ i hydrochlorotiazydu.

\section{Podsumowanie}

Należy podkreślić, że sartany to nowoczesna grupa leków hipotensyjnych o dobrych badaniach EBM, a wśród nich najlepiej przebadaną molekułą jest telmisartan.

Telmisartan wyróżnia się szczególnie korzystnym profilem farmakokinetycznym i wpływem na zaburzenia metaboliczne oraz dobrą tolerancją. Ważną cechą tego leku jest największe powinowactwo do wiązania z ludzkim ARB typu 1 spośród wszystkich preparatów z należących do grupy ARB i długi okres biologicznego półtrwania w surowicy krwi. Zapewnia to 24-godzinną skuteczność działania przeciwnadciśnieniowego pomiędzy kolejnymi dawkami leku, w tym także we wczesnych godzinach porannych. Ta cecha sprawia, że telmisartan jest najsilniejszym lekiem hipotensyjnym spośród wszystkich sartanów, co potwierdzily badania kliniczne head to head.

$\mathrm{Z}$ praktycznego punktu widzenia preparat ten $\mathrm{z}$ pewnością spełni oczekiwania $\mathrm{w}$ grupach pacjentów $\mathrm{z}$ wysokim ryzykiem sercowo-naczyniowym (ONTARGET), w zespole metabolicznym (SMOOTH), cukrzycy oraz $\mathrm{w}$ grupach chorych z powikłaniami nerkowymi (DETAIL, VIVALDI, AMADEO, TRENDY, INNOVATION).

Porównanie telmisartanu z ramiprylem w badaniu ONTARGET wykazało, że u osób obciążonych dużym ryzykiem sercowo-naczyniowym telmisartan będzie równie skuteczny w prewencji zdarzeń sercowo-naczyniowych jak ,złoty standard” ramipryl, a dodatkowo lepiej tolerowany, co zapewne przełoży się także na lepszy compliance w grupie leczonej telmisartanem.

$\mathrm{Na}$ tej podstawie i zgodnie z wytycznymi PTNT z 2015 roku można przyjąć, że jeżeli lekarz preferuje sartany lub istnieją przeciwwskazania do zastosowania inhibitora konwertazy, to telmisartan daje nie tylko gwarancję skutecznego leczenia hipotensyjnego, lecz również zwiększa prawdopodobieństwo najlepszego zabezpieczenia przed wystąpieniem groźnych powikłań ze strony układu sercowo-naczyniowego (choroby niedokrwiennej serca, udaru mózgu, choroby tętnic obwodowych) oraz cukrzycy typu 2 z uszkodzeniem narządu docelowego.

\section{Streszczenie}

W ostatnich latach nacisk w leczeniu nadciśnienia tętniczego został położony na indywidualizację terapii. Ostatnio opublikowane wytyczne Polskiego Towarzystwa Nadciśnienia Tętniczego opisują sytuacje szczególne w nadciśnieniu tętniczym, w których użycie antagonistów receptora AT1 (ARBs) jest wskazane. Blokowanie układu renina-angiotensyna-aldosteron odgrywa kluczową rolę w leczeniu nadciśnienia tętniczego i zapobieganiu jego narządowym powikłaniom. Wśród antagonistów receptora angiotensyny telmisartan wyróżnia się szczególnie korzystnym profilem farmakokinetycznym i wpływem na zaburzenia metaboliczne oraz dobrą tolerancją. 
Badania kliniczne potwierdzają jego skuteczność hipotensyjną oraz plejotropowe właściwości, prowadzące do poprawy funkcji śródbłonka, redukcji przerostu mięśnia lewej komory serca, nefroprotekcji, a także prewencji chorób mózgowo-naczyniowych u pacjentów z nadciśnieniem tętniczym. Największe $\mathrm{z}$ dotychczasowych, wieloośrodkowe, prospektywne, randomizowane, podwójnie ślepe badanie ONTARGET wykazało, że u chorych na nadciśnienie tętnicze, obciążonych dużym ryzykiem sercowo-naczyniowym, stosowanie telmisartanu było równie skuteczne pod względem zapobiegania incydentom sercowo-naczyniowym, a dodatkowo lepiej tolerowane niż leczenie ramiprylem.

słowa kluczowe: telmisartan, antagoniści receptora angiotensyny II, nadciśnienie tętnicze, zalecenia

Arterial Hypertens. 2015, tom 19, nr 4, strony 145-151

DOI: 10.5603/AH.2015.0019

\section{Piśmiennictwo}

1. Wytyczne ESH/ESC dotyczące postępowania w nadciśnieniu tętniczym w 2013 roku. Nadciśn. Tętn. 2013; 17: 69-168.

2. Tykarski A., Narkiewicz K., Gaciong Z. i wsp. Zasady postępowania w nadciśnieniu tętniczym -2015 rok. Wytyczne Polskiego Towarzystwa Nadciśnienia Tętniczego. Nadciśn. Tętn. Prakt. 2015; 1: $1-70$.

3. Widecka K., Grodzicki T., Narkiewicz K. i wsp. Zasady postępowania w nadciśnieniu tętniczym - 2011 rok. Wytyczne Polskiego Towarzystwa Nadciśnienia Tętniczego. Nadciśn. Tętn. 2011; 15: 55-82.

4. The ONTARGET Investigators. Telmisartan, ramipril or both in patients at high risk for vascular events. NEJM 2008; 358: 1547-1559.

5. The TRANSCEND Investigators. Effects of the angiotensin-receptor blocker telmisartan on cardiovascular events in high-risk patients intolerant to angiotensin-converting enzyme inhibitors: a randomised controlled trial. Lancet 2008; 372: 1174-1183.

6. Burnier M., Brunner H.R. Angiotensin II receptor antagonists. Lancet 2000; 355: 637-645.

7. Wienen W., Enthzerod M., van Meel J.C.A. i wsp. A review on telmisartan: a novel, long acting aniotensin II-receptor antagonist. Cardiovasc. Drug Rev. 2000; 18; 127-156.

8. Kakuta H. Telmisartan has the strongest binding affinity to angiotensin II type 1 receptor: comparison with other angiotensin II type 1 receptor blockers. Int. J. Clin. Pharmacol. Res. 2005; 25: 41-46.

9. Neutel J.M. Ambulatory blood pressure monitoring to assess the comparative efficacy and duration of action of a novel new angiotensin II receptor blocker — telmisartan. Blood Press 2001; 10 (supl. 4): 27-32.

10. Kario K., Pickering T.G., Umeda Y. i wsp. Morning surge in blood pressure as predictor of silent and clinical cerebrovascular disease in elderly hypertensives. A prospective study. Circulation 2003; 107: 1401-1406.

11. Ragot S., Ezzaher A., Meunier A. Comparison of trough effect of telmisartan vs perindopril using selfblood pressure measurement: EVERESTE study. J. Hum. Hypertens. 2002; 16: 865-873.

12. Vogt L., Liffert G., Navis J. i wsp. on behalf of the Angiotensin II Receptor Antagonist Telmisartan Micardis in Isolated Systolic Hypertension (ARAMIS) Study Group. The angiotensin II receptor antagonist telmisartan reduces urinary albumin excretion in patients with isolated systolic hypertension: results of a randomized, double-blind, placebo-controlled trial. J. Hypertens. 2005; 23: 2055-2061.

13. Williams B., Gosse P., Lowe L. i wsp. The prospective, randomized investigation of the safety and efficacy of telmisartan versus ramipril using ambulatory blood pressure monitoring (PRISMA I). Hypertens. 2006; 24: 193-200.
14. White W.B., Lacourciere Y., Davidai G. Effects of the angiotensin II receptor blockers telmisartan versus valsartan on the circadian variation of blood pressure: impact on the early morning period. Am. J. Hypertens. 2004; 17: 347-353.

15. Lacourcière Y., Martin K. Efficacy and tolerability of a fixed-dose combination of telmisartan plus hydrochlorothiazide in patients uncontrolled with telmisartan monotherapy. J. Hum. Hypertens. 2001; 15: 763-770.

16. Neutel J.M., Littlejohan T.W., Chrysant S.G., Singh S.A. Telmisartan/hydrochlorothiazide in comparison with losartan/hydrochlorothiazide in managing patients with mild-to-moderate hypertension. Hypertens. Res. 2005; 28: 555-563.

17. Haffner S.M. Risk constellations in patients with metabolic syndrome: epidemiology, diagnosis and treatment patterns. Am. J. Med. 2006; 119 (supl. 5A): S3-S9.

18. Vitale C., Mercuro G., Castiglioni C. i wsp. Metabolic effect of telmisartan and losartan in hypertensive patients with metabolic syndrome. Cardiovasc. Diabetol. 2005; 4: 6.

19. Nagel J.M., Tietz A.B., Goke B. i wsp. The effect of telmisartan on glucose and lipid metabolism in nondiabetic, insulin-resistant subjects. Metabolism 2006; 55: 1149-1154.

20. Benson S.C., Pershadsingh H.A., Ho C.I. i wsp. Identification of telmisartan as a unique angiotensin II receptor antagonist with selective PPARg-modulating activity. Hypertension 2004; 43: 993-1002.

21. Barnett A.H., Bain S.C., Bouter P. i wsp. Diabetic Exposed to Telmisartan and Enalapril Study Group. Angiotensin - receptor blockade versus converting - enzyme inhibition in type 2 diabetes and nephropathy. N. Engl. J. Med. 2004; 351: 952-1961.

22. Schmieder R.E., Delles C., Mimran A. i wsp. Impact of telmisartan versus ramipril on renal endothelial function in patients with hypertension and type 2 diabetes. Diabetes Care 2007; 30: 1351-1356.

23. Galle J., Schwedhelm E., Pinnetti S. Antiproteinuric effects of angiotensin receptor blockers: telmisartan versus valsartan in hypertensive patients with type 2 diabetes mellitus and overt nephropathy. Nephrol. Dial. Transplant. 2008; 23: 3174-3183.

24. Bakris G., Burgess E., Weir M., Davidai G., Koval S.; AMADEO Study Investigators. Telmisartan is more effective than losartan in reducing proteinuria in patients with diabetic nephropathy. Kidney Int. 2008; 74: 364-369.

25. Makino H., Haneda M., Babazono T., Moriva T. Microalbuminuria reduction with telmisartan in normotensive and hypertensive Japanese patients with type 2 diabetes: a post-hoc analysis of The Incipient to Overt: Angiotensin II Blocker, Telmisartan, Investigation on Type 2 Diabetic Nephropathy (INNOVATION) study. Hypertens. Res. 2008; 31: 657-664.

26. Asmar R., Gosse P., Topouchian J., Ntela G., Gray S., Dudley A. Effects of telmisartan on arterial stiffness in type 2 diabetes patients with essential hypertension. JRAAS 2002; 3: 176-180.

27. Schmieder R.E., Delles C., Mimran A. i wsp. Impact of telmisartan versus ramipril on renal endothelial function in patients with hypertension and type 2 diabetes. Diabetes Care 2007; 30: 1351-1356.

28. MacMahon S., Peto R., Cutler J. i wsp. Blood pressure, stroke, and coronary heart disease. Part 1: Prolonged differences in blood pressure. Prospective observational studies corrected for the regression dilution bias. Lancet 1990; 355: 765-774.

29. Collins R., Peto R., MacMahon S. i wsp. Blood pressure, stroke, and coronary heart disease. Part 2: Short-term reductions in blood pressure. Overview of randomized drug trials in their epidemiological context. Lancet 1990; 355: 827-838.

30. Masaru I., Hong-Wei L., Rui C. i wsp. Possible Inhibition of Focal Cerebral Ischemia by Angiotensin II Type 2 Receptor Stimulation. Circulation 2004; 110: 843-848.

31. Yusuf S., Diener H.C., Sacco R.L. i wsp.; PRoFESS Study Group. Telmisartan to prevent recurrent stroke and cardiovascular events. N. Engl. J. Med. 2008; 359: 1225-1237.

32. Neldam S., Edwards C.; ATHOS Study Group. Telmisartan plus hydrochlorothiazide compared with amlodipine plus hydrochlorothiazide in older patients with systolic hypertension: Results from a large ABPM study. Am. J. Geriat. Cardiol. 2006; 15: $151-160$ 
